\title{
Effect of Physics Education Technology (PhET) Simulations: Evidence from STEM Students' Performance
}

\author{
Ananias N. Yunzal, $\mathrm{Jr}^{{ }^{*}}$, Leomarich F. Casinillo ${ }^{2}$
}

${ }^{1}$ Baybay City Senior High School, Baybay City, Leyte, Philippines

${ }^{2}$ Visayas State University, Baybay City, Leyte, Philippines

A R T I C L E I N F O

Article history:

Received 23 July 2020

Received in revised

Form 09 August 2020

Accepted 19 August

2020

Available online 30

August 2020

Keywords:

PhET simulations;

electrodynamics; quasi-

experimental type; STEM

students' performance

\section{A B S T R A C T}

This study aimed to find out if Physics Education Technology (PhET) simulations can improve the performance of the Baybay City Senior High School STEM students on the selected topic in physics, that is, electrodynamics. This study utilized a quasi-experimental type where pre-test and post-test are multiple choice type of test and involved 72 STEM students. The grouping of the students was identified based on their sections, one section served as the control group and other is the experimental group. Experimental group is allowed to play the PhET simulation for an hour utilizing their vacant period every day, while the control is not exposed to any activity that intervene leading to the creation of formal construct of ideas in electrodynamics. Result showed that mean scores of the control and experimental groups does not imply a significant difference, despite of the interest shown by the students in playing the said simulation. Perhaps, students are more attracted to simulation in which they have gone through during their lectures. Furthermore, study shows that the performance of students before and after exposure to PhET simulation does not necessarily pose a big difference but indicates a slight improvement to their performances.

\section{Introduction}

Physics is one of the subjects in high school where student's interest is profoundly less due to its complex and abstract form. As reported, the status of the physics education in the Philippines is facing challenges. In which challenges resulted to low academic performance that is deeply-rooted concern by the Philippine education system (Casinillo \& Aure, 2018; Sarmiento \& Orale, 2016). One of the challenges, faced is the lack of equipment in physics instruction (Orleans, 2007). In relation to this, there must be an intervention on how to increase the interest of the students to learn more Physics in a more meaningful manner. (Schwartz et al., 2005) emphasized that students learn only a little when the concepts are present in traditional classroom demonstration and that there must be engagement to increase the efficacy of learning.

The performance of the students in Physics nowadays is declining due to challenging problems (Mekonnen, 2014). This declining pattern of the students' performance in Physics is based on the different researches and studies administered by the different researchers (Adams, 2010; Batuyong \& Antonio, 2018; Podolefsky et al., 2009; Rutten et al., 2012; Scheid et al., 2010) stated that performance of students in Physics is a scenario that needs to be addressed by teachers which is a challenge of Science educators to devise or innovate ways to make teaching-learning stimulating. For this reason, Physics educators should find ways and interventions such that it can enhance the performance of the students in the said field (Antonio, 2015).

Most of the researchers shows that the use of instructional materials can improve the learning of learners. The use of laboratory manuals and learning modules (Orleans, 2007), computer-assisted instructional program (Waight \& Abd-El-Khalick, 2007) and other digital technologies (Armstrong \& 
Casement, 2000; Pittard et al., 2003) proved that there is effective transfer and acquisition of learning and development of skills. According to (Batuyong \& Antonio, 2018), integrating ICT-supported education in the teaching-learning process is a great concern in K-12 schools in the Philippines for the improvement of level of achievement. In fact, one of the studies related to computer aided instruction showed that students who were introduced to such technology performed better that the students who did not use such where this study was conducted for junior and senior high school students (Mullis et al., 2016). In the study of (Casinillo et al., 2020; Meggiolaro, 2018), instructional materials involving technology has shown to help students to be creative and shown more authentic learning environments where the students are more motivated. Furthermore, technology has shown to have a greater chance of communication between teacher and students.

Nowadays, the rampant usage of information communication technology (ICT) is increasing (Prestridge, 2012). And that, ICT addresses the gap between teaching and learning process, hence can be used in the science teaching (Waight \& Abd-El-Khalick, 2007). One of the promising technology that facilitates learning is the computer simulations in physics or Physics Education Technology (PhET) simulation. PhET simulation is considerably a powerful tool in achieving the learning of student in science (Adams, 2010). The integration of PhET in class can be of help in addressing the necessity of creating a construct framework of scientific understanding. According studies related to computer aided instructions, computers and other computer related instructional materials pave the enhancement of the performance of the learners (Waight \& Abd-El-Khalick, 2007). It mean therefore that the use of computer simulations can enhance the performance of the students towards Physics. In relation to this, PhET simulations can be an effective tool in increasing the performance of the students.

Summing up, this study is to find the significant improvement of grades of students with the aid of an intervention, the PhET simulations. The results of this study will be utilized as an empowering tool to enhance the performance of the students leading to the increase of the level of performance of Science in Baybay City Division, Philippines. In general, the aim of this study is to find out if PhET simulations can improve the academic performance Baybay City Senior High School (BCSHS) STEM students on selected topic in Physics. Specifically, this study answers the following objectives: (1) to determine the level of achievement of BCSHS STEM students with no intervention and with intervention of PhET simulations; and (2) to determine the significant difference of performances between students using PhET simulations and without interventions. This study intends to contribute to the following identified beneficiaries, namely: a) Students, b) teachers, c) school administrators and DepEd Baybay City division. With the use of $\mathrm{PhET}$ simulations, students will be able to have a grasp of concepts in Physics, thus providing a better understanding to the concepts of the subject matter. Teachers will be able to minimize time in preparing activities which are readily available in virtual simulations that can be installed in e-classrooms. School administrators will not necessitate themselves to purchase laboratory equipment to be provided to the students for their better learning. To Baybay City Division, this study would be relevant in the sense that it would increase the performance of the students thus increasing the Mean Percentage Scores (MPS), particularly in sciences.

\section{Methods}

The research study employed a quasi-experimental that utilizes pre-test and post-test design in order to determine the significant effect of PhET simulation on the learning improvement of the students. Some descriptive statistics was used in describing the data set. Furthermore, for the inferential statistics, T-test for significant difference was used to determine the improvement of students or significant effect of PhET simulation on the learning.

The student participants involved in this study were 72 grade 12 STEM students of Baybay City Senior High School. The selection to be used is cluster sampling according to section grouping. There were two groups that were selected - one group for the control group (40 STEM students) and the other for the experimental group (32 STEM students). In both of the groups, pre-test and post-test was administered to commensurate the improvement of their learning due to the implementation of PhET simulation intervention.

The instrument used in the study was a Multiple-Choice Test questionnaire and Zipgrade application was used to facilitate the checking. The questions used in the pre-test and post were taken from the book Practicing Physics Conceptual Physics (Hewitt, 2006). The test involved on the conceptual understanding of electrodynamics, one of the topics in physics. Both the control and experimental groups has taken the pre-test to measure their learning prior to the implementation of PhET simulations. During the administration of the intervention, the PhET simulations, vacant schedule of the experimental students was utilized and post-test was administered after to see the differences of their conceptual 
understanding of the topics being assessed. The control group was not exposed to any treatment or intervention and post-test was administered after the discussion of lessons with traditional teaching strategy. In other words, the vacant schedule of the control students were not utilized. To note further, the said groups of students will not be exposed to lecture or any related activities that will enable them to create a construct of ideas prior to exposure to PhET simulations.

In the analysis of the data, Paired and Independent T-test was administered to compare the significant difference between the pre-test and post-test of the experimental group, and the posttest experimental group and posttest control group, respectively (Walpole, 1982). In line with this, descriptive statistics was also administered to describe the characteristics of the gathered data such as mean, standard deviation, minimum and maximum value.

\section{Result and Discussion}

\section{Result}

Descriptive Statistics for Pre-test and Posttest Scores

Table 1. Descriptive statistics of control and experimental groups' pre-test and post-test.

\begin{tabular}{ccccc}
\hline Descriptive & \multicolumn{2}{c}{ Control Group (n=40) } & \multicolumn{2}{c}{ Experimental Group (n=32) } \\
\cline { 2 - 5 } Statistics & Pre-test & Post-test & Pre-test & Post-test \\
\hline Mean & 3.33 & 3.70 & 3.43 & 3.97 \\
Std. dev. & 0.2069 & 0.2562 & 0.2616 & 0.2176 \\
Minimum & 1 & 1 & 1 & 2 \\
Maximum & 6 & 8 & 7 & 8 \\
\hline
\end{tabular}

Note: Highest possible score is 10 .

\section{T-test Analysis}

Table 2. Statistical t-test results for control and experimental post-test mean scores

\begin{tabular}{cccc}
\hline Variables & T-computed & df & $p$-value \\
\hline Control vs Experimental & $-0.7995 \mathrm{~ns}$ & 70 & 0.2133 \\
\hline
\end{tabular}

Note: ns-not significant.

Table 3. Statistical t-test results for experimental pre-test and post-test mean scores

\begin{tabular}{cccc}
\hline Variables & T-computed & df & -value \\
\hline Pre-test vs Post-test & $-1.745^{*}$ & 31 & 0.045 \\
\hline Note: $*_{-}^{-}$significant at 5\% level. & & &
\end{tabular}

Note: *- significant at $5 \%$ level.

\section{Discussion}

As the first step, descriptive statistics was performed to see the nature and characteristics of the data results. This descriptive nature of the data presented enable to compare the values of the results which can indicate relative differences. Table 1 shows that for the control group and experimental group, the mean scores are low which implies that the physics test is difficult for the students and further implies that they are facing some challenging problems. Under the posttest score of experimental groups, the maximum score is 8 out of 10 and the minimum is 2 . This goes to infer that there are several students find the test difficult and indicating that PhET interactive simulations has a slight effect to their level of achievement. It is also shown in the means score that there is only small difference between the pre-test and post-test. This result is not consistent to the study of (Adams, 2010; Batuyong \& Antonio, 2018) that the level of achievement of students after the implementation of PhET shows a tremendous increase. This low performance is due to some factors that negatively influencing while implementing the said intervention (Casinillo, L. F. \& Casinillo, 2020; Casinillo, 2019; Sangcap, 2010) and due to challenging problems that students might encounter (Mekonnen, 2014).

Table 2 shows the result of the t-test analysis comparing the means of the control group and experimental group post-test mean scores. The results show a big probability value (0.21) which signifies then that there is no significant difference between the mean scores of the control and experimental groups' post-test at $5 \%$ significance level. To some extent, the statistical analysis of the means of control 
and experiment groups means that the intervention provided to the students does not necessarily gives a hypothesized outcome that enhance the performance of the students as manifested in their test scores that is considerably low. Although, there are scores in the experimental group which considerably high, however it behaves like an outlier data in the score distribution. This goes to infer that PhET simulations has no significant effect to the students learning which is not parallel to the outcome of (Adams et al., 2008; Hsin et al., 2014).

Further statistical analysis was done on the pre-test and post-test means in the experimental group as shown in Table 3. Although it is clear that there is a considerable deviation in their means, however it is noted that the t-test result shows a small significant difference. In addition, the scores of the respondent mostly does not attain the passing rate which also implies that the intervention made does necessarily affect the conceptual behaviour of the students toward physics.

It is worthy to note however that during the administration of the PhET simulation, students were interested and creative in exploring the different simulations in Physics (Beghetto, 2016). Despite of the fact that they were instructed to discover and play simulations related to the concept of electricity and magnetism they tend to explore beyond what they limited to do so. They were interested in exploring the simulations related to the tackled concepts in physics during their lectures (Bahr \& Rieth, 1989). As per observation during the activity, the exploration of the students to PhET is more inclined to the concepts they have had already, where they explored more on the mechanics topics in physics. Students somehow are being ironical as to what are the limitations set and given to them as to what coverage of simulations should be exposed with.

Despite of the fact that the results of the tests administered a slight difference of the pre-test and post-test of both experimental and control group, it is worthy to note that students are interested towards the computer simulations. Good interest in the learning process can improve the academic performance and happiness in learning which is similar to the studies of (Abecia et al., 2014; Bailey, 2009; Casinillo \& Aure, 2018). For the Physics teacher side, implementing PhET can improve their teaching strategy which is very important in classroom environment (Casinillo \& Guarte, 2018; Fokkens-Bruinsma \& Canrinus, 2012). This simulation on the other hand, based on the result is not good in the creation of the formal construct of concepts in physics the students. This is because students have a hard time in understanding the different terminologies that can be found in the said simulations. Based on the observation it is necessary that the students should be exposed first to lectures or any other activity that will enable the students to learn the different terminologies associated to physics. This declaration is due to the fact that the students are more inclined to explore simulations in which they have gone through already in their lectures. It also important to note that the non-interference of the lectures and other activities related to, that would elicit the conceptual understanding of the students might have affected the interest of the students to explore the set and specified simulations (Adams, 2010; Rutten et al., 2012). Another observation is that the nature of the PhET simulation does not necessarily pave the creation of formal construct of knowledge or ideas related to physics rather it verifies such ideas that had been learned, using the virtual laboratory nature of the said simulation (Moore et al., 2014; Podolefsky et al., 2010). In summary, this findings were supported in a study by (Batuyong \& Antonio, 2018) who found out that learning experiences gained by the STEM students in implementing PhET simulations can be deduced into three big themes: learning Physics is fun, real, simple and easy.

\section{Conclusion}

The result of the study shows that PhET simulation has revealed a low improvement to the students' performance in the conceptual assessment in electrodynamics. In other words, the conduct of this study therefore, revealed that PhET simulation can improve the academic performance of the STEM students towards physics in a slight manner. Conclusively, the performance of students who are exposed to PhET simulation and to those who were not exposed does necessarily pose a small difference showing that PhET simulation is an effective tool in teaching and improving students' level of achievement in Physics subject. Hence, Physics teachers should be given room for improvement and further uplift to a higher level of Physics Education Technology (PhET) implementation to further meet the desired instructional objectives of Department of Education (DepEd) for the sake of well-being of students. In implementing PhET simulations, STEM students can be said to be enjoying what they are doing. Hence, physics teachers should maintain and enrich the provision of activities in PhET simulations so that students will learn Physics with enjoyment. 


\section{References}

Abecia, D. R., Samong, M., Abella, L., Baldomero, F., Tamayo, A., \& Gabronino, R. (2014). Measuring Happiness of University Students. Sciences, American Journal of Social, 2(3), 43-48.

Adams, W. K. (2010). Student Engagement and Learning with PhET Interactive Simulations. Il Nuovo Cimento C, 33(3), 21-32.

Adams, W. K., Reid, S., LeMaster, R., McKagan, S., Perkins, K., Dubson, M., \& Wieman, C. E. (2008). A Study of Educational Simulations Part II-Interface Design. Journal of Interactive Learning Research, 19(4), 551-577.

Antonio, V. V. (2015). Adoption and Use of ICT in the Management of Public Secondary Schools. Mariano Marcos State University, Laoag City.

Armstrong, A., \& Casement, C. (2000). The Child and the Machine: How Computers. Robins Lane Press.

Bahr, C. M., \& Rieth, H. J. (1989). The effects of Instructional Computer Games and Drill and Practice Software on Learning Disabled Students' Mathematics Achievement. Computers in the Schools, 6(4), 87-102.

Bailey, R. (2009). Well-being, Happiness and Education. British Journal of Sociology of Education, 30(6), 795-802. https://doi.org/10.1080/01425690903236613

Batuyong, C. T., \& Antonio, V. V. (2018). Exploring the Effect of PhET Interactive Simulation- Based Activities on Students' Performance and Learning Experiences in Electromagnetism. Asia Pacific Journal of Multidisciplinary Research, 6(2), 121-131.

Beghetto, R. A. (2016). Creative learning: A fresh look. Journal of Cognitive Education and Psychology, 15(1), 6-23.

Casinillo, L. F. \& Casinillo, E. L. (2020. (2020). Modelling Experiences and its Factors in General Mathematics: The Case of Grade 11 Students. Indonesian Journal of Educational Research and Review, 3(2), 25-34.

Casinillo, L. F. (2019). Factors affecting the failure rate in mathematics: the case of Visayas State University (VSU). Review of Socio-Economic Research and Development Studies, 3(1), 1-18.

Casinillo, L. F., \& Aure, M. R. K. L. (2018). ). Econometric evidence on academic performance in basic calculus of science, technology, engineering and mathematics (STEM) senior high students. Journal of Educational and Human Resource Development, 6, 238-249.

Casinillo, L. F., Camulte, M. C. G., Raagas, D. L., \& Riña, T. S. (2020). Cultural factors in learning mathematics: the case on achievement level among Badjao students. International Journal of Indonesian Education and Teaching, 4(1), 71-81.

Casinillo, L. F., \& Guarte, J. M. (2018). Evaluating the effectiveness of teaching strategies: The case of a national vocational school in Hilongos, Leyte. Review of Socio-Economic Research and Development Studies, 2(1), 64-79.

Fokkens-Bruinsma, M., \& Canrinus, E. T. (2012). Adaptive and Maladaptive Motives for Becoming a $\begin{array}{llll}\text { Teacher. Journal of Educational } & \text { Teaching, }\end{array}$ https://doi.org/10.1080/02607476.2012.643652

Hewitt, P. G. (2006). Practicing Physics Conceptual Physics (10 th). Pearson Education Inc.

Hsin, C. T., Li, M. C., \& Tsai, C. C. (2014). The influence of young children's use of technology on their learning: A review. Journal of Educational Technology \& Society, 17(4), 85-99.

Meggiolaro, S. (2018). Information and communication technologies use, gender and mathematics achievement: evidence from Italy. Social Psychology of Education, 21(2), 497-516.

Mekonnen, S. (2014). Problems challenging the academic performance of physics students in higher governmental institutions in the case of Arbaminch, Wolayita Sodo, Hawassa and Dilla Universities. Natural Science, 6, 362-375.

Moore, E. B., Chamberlain, J. M., Parson, R., \& Perkins, K. K. (2014). PhET interactive simulations: Transformative tools for teaching chemistry. Journal of Chemical Education, 91(8), 1191-1197. 
Mullis, I. V. S., Martin, M., \& Tom, L. (2016). 20 Years of TIMSS: International Trends in Mathematics and Science Achievement Curriculum and Instruction. International Association for the Evaluation of Educational Achievement (IEA).

Orleans, A. V. (2007). The condition of secondary school physics education in the Philippines: Recent developments and remaining challenges for substantive improvements. The Australian Educational Researcher, 34(1), 33-54.

Pittard, V., Bannister, P., \& Dunn, J. (2003). The big pICTure: The impact of ICT on attainment, motivation and learning. DIES.

Podolefsky, N. S., Perkins, K. K., \& Adams, W. K. (2010). Factors promoting engaged exploration with computer simulations. Physical Review Special Topics-Physics Education Research, 6(2), 102-117.

Podolefsky, N. S., Perkins, K. K., \& Adams, W. K. (2009). Computer simulations to classrooms: tools for change. AIP Conference Proceedings, 233-236.

Prestridge, S. (2012). The beliefs behind the teacher that influences their ICT practices. Computers \& Education, 58(1), 449-458.

Rutten, N., Van Joolingen, W. R., \& Van Der Veen, J. T. (2012). The learning effects of computer simulations in science education. Computers \& Education, 58(1), 136-153.

Sangcap, P. G. A. (2010). Mathematics-related beliefs of Filipino college students: Factors affecting mathematics and problem solving performance. Procedia - Social and Behavioral Science, 8(1), 465475. https://doi.org/10.1016/j.sbspro.2010.12.064

Sarmiento, D. H., \& Orale, R. L. (2016). Senior high school curriculum in the Philippines, USA and Japan. Journal of Academic Research, 1(3), 12-23.

Scheid, J., Müller, A., Schnotz, W., Hettmannsperger, R., Kuhn, J., Telli, S., \& Vogt, P. (2010). Development of Representational Competence via Cognitively Activating Tasks for Physics Experiments. GIREP Conference in Reims.

Schwartz, D., Bransford, J. D., \& Sears, D. (2005). Efficiency and Innovation in Transfer : Transfer of Learning from a Modern Multidisciplinary Perspective. JP Mestre.

Waight, N., \& Abd-El-Khalick, F. (2007). The impact of technology on the enactment of "inquiry" in a technology enthusiast's sixth grade science classroom. Journal of Research in Science Teaching, 44(1), 154-182.

Walpole, R. E. (1982). Introduction to statistics. McMillan Publishing Co., Inc. 